\title{
Lipid production in Dunaliella bardawil under autotrophic, heterotrophic and mixotrophic conditions
}

\author{
Zohreh Zare Chavoshi ${ }^{1}$, Mansour Shariati ${ }^{1} *_{\mathbb{B}}$
}

${ }^{1}$ University of Isfahan

(Department of Biology, Hezar Jarib St, Isfahan, Iran).

*Corresponding author: mansour_shariati@yahoo.com

mansour@sci.ui.ac.ir

\section{ABstract}

Many microalgae are rich in lipid. Due to their low growth rates in the autotrophic culture, the best alternative is to cultivate cells under different conditions such as heterotrophic or mixotrophic, which results in the highest yield of biomass and lipid in the shortest duration. In this study, Dunaliela bardawil (UTEX 2538) green microalgae was cultivated under different culture conditions, autotrophic, heterotrophic and mixotrophic, and effects on cell concentration, lipid production and reactive oxygen species (ROS), total chlorophyll and beta-carotene concentrations were investigated. Due to very low cellular growth, this alga is not recommended for heterotrophic culture. In terms of mixotrophic conditions containing different concentrations of glucose or acetate, the highest cell growth and lipid production in $60 \mathrm{mM}$ glucose was similar to the control (autotrophic condition), while the concentrations of chlorophyll and beta-carotene decreased. However, at all concentrations of acetate, a slight increase in cell growth was achieved, while the lipid content decreased. Additionally, the concentrations of chlorophyll and beta-carotene increased. A positive correlation was observed between beta-carotene biosynthesis and lipid production, as well as levels of reactive species of oxygen and lipid production in the presence of glucose and acetate. This study showed that for $D$. bardawil the mixotrophic culture with $60 \mathrm{mM}$ glucose was the most suitable type of culture for increasing lipid content and cell growth rates in less time (one week).

Descriptors: beta-carotene, cell growth, chlorophyll, culture condition, reactive oxygen species.

\section{INTRODUCTION}

Lipids are vital for the growth and survival of all organisms. They are important structural compounds of cell membranes and play an important role as energy and carbon reservoirs (De Swaaf et al., 2003). The accumulation of lipids in microalgae depends on several factors (Takagi and Karseno, 2006), including growth conditions (Schenk et al., 2009), whether inorganic or organic carbon sources are used (De Swaaf et al., 2003), and specific strains of microalgae (Chisti, 2007). Most microalgae growth under autotrophic conditions, but subject to low biomass production, low lipid content and a long period of cultivation to reach exponential growth (Martinez and Orus, 1991). Therefore, heterotrophic and mixotrophic cultures have been proposed as alternatives for mass biomass production and cellular lipid accumulation in microalgae (Yu et al., 2009).

The heterotrophic culture involves the use of organic compounds such as sugars and organic acids as the only

Submitted on: 17/January/2019

Approved on: 12/August/2019

http://dx.doi.org/10.1590/S1679-87592019024906709

Editor: Rubens M. Lopes carbon and energy sources in the absence of light (Chojnacka et al., 2004). Some studies have shown that such approach may increase the production of biomass and lipids in microalgae (Miao and Wu, 2006; Boyle and Morgan, 2009). In mixotrophic cultures, organic and inorganic carbon sources are used simultaneously in the presence of light (Chojnacka et al., 2004), and photosynthesis and respiration occur simultaneously (Lee, 2004; Sun et al., 2008).

In the pathway for lipids biosynthesis (Ren et al., 2009), acetyl coenzyme A (acetyl-CoA) acts as a precursor. Cytosolic storage pathways for acetyl-CoA are dependent on organic carbon sources used for growth, such as glucose and acetate. The main route of carbon from glucose to cytosolic acetyl-CoA includes glycolysis, the transfer of pyruvate to mitochondria, the conversion of pyruvate to citrate, transfer of citrate to cytosol, and the conversion of citrate by ATP-citrate lyase to acetyl-CoA. The conversion of acetate to acetyl-CoA involves a onestep enzyme reaction catalyzed by acetyl-CoA synthase (Ratledge and Evans, 1989).

Dunaliella is a single-cell green alga belonging to the class Chlorophyceae (Capa-Robles et al., 2009). Due to the lack of cell wall in Dunaliella, the extraction of 
produced materials is much cheaper than other algae and plants (Hosseini Tafreshi and Shariati, 2006). Dunaliella species are able to survive in a wide range of salinity (BenAmotz, 2004) due to their ability to collect large amount of glycerol (Ben-Amotz et al., 1982). Some Dunaliella species such as $D$. bardawil ( $=D$. salina; Borowitzka, 2016) can produce high amounts of beta-carotene (Vanitha et al., 2007) in response to some stress conditions such as intense light, high salinity, and low nutrient concentration (Hosseini Tafreshi and Shariati, 2006). Dunaliella species are able to store lipids (Gouveia and Oliveira, 2009) as well as glycerol, which is used as a lipid storage in microalgae in biosynthesis pathway of triacylglycerides (Sharma et al., 2012). Therefore, optimizing the growth conditions are essential for high lipid production (Borowitzka, 1999).

Hence, in this study, the effects of different nutritional conditions (autotrophic, heterotrophic and mixotrophic cultures), as well as organic carbon inputs (glucose and acetate) on the cell growth and production of Dunaliella bardawil ( $=$ D. salina) were investigated. We aimed to identify culture conditions that can lead to the highest levels of lipid production in D. bardawil $(=D$. salina $)$ in the shortest time interval, without reducing cell growth rates.

\section{MATERIAL AND METHODS}

\section{Microalgal STRAIN AND CULTURE MEDIUM}

Dunaliella bardawil $(=D$. salina) was obtained from the University of Texas Culture Collection (UTEX 2538). The original cultures were maintained in modified (Shariati and Lilley, 1994) Johnson's solution (Johnson et al., 1968), composed of $\mathrm{KNO}_{3} 5 \mathrm{mM}, \mathrm{CaCl}_{2} 0.2 \mathrm{mM}, \mathrm{MgSO}_{4} \cdot 7 \mathrm{H}_{2} \mathrm{O}$ $5 \mathrm{mM}, \mathrm{KH}_{2} \mathrm{PO}_{4} 0.2 \mathrm{mM}, \mathrm{CuCl}_{2} 1 \mu \mathrm{M}, \mathrm{Zncl}_{2} 1 \mu \mathrm{M}, \mathrm{MnCl}_{2}$ $7 \mu \mathrm{M},\left(\mathrm{NH}_{4}\right)_{6} \mathrm{Mo}_{7} \mathrm{O}_{24} \cdot 4 \mathrm{H}_{2} \mathrm{O} 1 \mu \mathrm{M}, \mathrm{CoCl}_{2} 1 \mu \mathrm{M}, \mathrm{FeCl}_{3} 6 \mathrm{H}_{2} \mathrm{O}$ $4 \mu \mathrm{M}, \mathrm{Na}_{2}$ EDTA $10 \mu \mathrm{M}, \mathrm{NaCl} 1.5 \mathrm{M}$. The $\mathrm{pH}$ of the culture medium was adjusted in the range of 7-7.5. The culture medium was sterilized in an autoclave for $15 \mathrm{~min}$ at $121^{\circ} \mathrm{C}$. The cells were cultured in $100 \mathrm{~mL}$ of the culture medium, and were inoculated with $10 \%(\mathrm{v} / \mathrm{v})$ cells. The cultures were kept at $27^{\circ} \mathrm{C}, 16 / 8 \mathrm{~h}$ light/dark regime under continued shaking at 110 rpm (INFORS shaker AG CH - 4103, Bottmingen).

\section{Culture methods}

For the control (autotrophic condition) culture, $25 \mathrm{mM}$ of $\mathrm{NaHCO}_{3}$ were added to the culture medium as inorganic carbon source, at a fluorescent light intensity of $100 \mu \mathrm{mol}$ photons $\mathrm{m}^{-2} \mathrm{~s}^{-1}$ (SQPR Hansatech, UK) and a $16 / 8 \mathrm{~h}$ light/dark photoperiod for 14 days. For the heterotrophic culture, the organic carbon sources glucose (at zero, 20, 40, 60 and $80 \mathrm{mM}$ ) and acetate (at zero, 50, 100 and $150 \mathrm{mM}$ ) were used. The algal cultures were placed under dark condition and wrapped in aluminum foil, for 14 days. The mixotrophic culture was kept under the same light and inorganic carbon conditions as in the autotrophic culture, and organic carbon was added as glucose (at zero, 20, 40, 60 and $80 \mathrm{mM}$ ) and acetate (at zero, 50, 100 and $150 \mathrm{mM}$ ). After autoclaving the culture medium, glucose and acetate solutions were filtered separately using $0.22 \mu \mathrm{m}$ pore size filter membrane and added to the culture whenever needed.

\section{ANALYTICAL METHODS}

Sampling for cell counting and measuring chlorophyll and beta-carotene concentrations was carried out at the onset of the experiments and after 4, 7,10 and 14 days. The total lipid content was measured at the beginning of the experiment and after 7 and 14 days.

To measure the cell concentration, $200 \mu$ l of the algal suspension were removed and $10 \mu$ l of formaldehyde solution was added; counts were performed with a hemocytometer under a regular microscope (Olympus $\mathrm{CH}$ 3 ORF 200). The final result was calculated as cells per $\mathrm{mL}$ (Schoen, 1988).

Chlorophyll and beta-carotene concentrations were estimated in $1 \mathrm{~mL}$ of algal culture, after centrifugation at $13000 \mathrm{rpm}$ for 6 min (Eppendorf AG 22331 Hamburg). The supernatant was removed and $1 \mathrm{~mL}$ of $80 \%$ acetone was added to the pellet. After centrifugation at $13000 \mathrm{rpm}$ for $4 \mathrm{~min}$, the absorption of the supernatant was read using a spectrophotometer (Shimadzu UV-160A) at 412, 431, 460 and 480nm, and chlorophyll a (Chla), chlorophyll b (Chlb) and beta-carotene concentrations were estimated with the following equations (Eijckelhoff and Dekker, 1997):

$$
\begin{aligned}
& \mathrm{Chl}_{\mathrm{a}}=-1.709 A_{412}+11.970 A_{431}-2.998 A_{460}-5.708 A_{480} \\
& \mathrm{Chl}_{\mathrm{b}}=-0.171 A_{412}-0.230 A_{431}+11.871 A_{460}-13.248 A_{480} \\
& \text { Total chlorophyll }=\mathrm{Chl}_{\mathrm{a}}+\mathrm{Chl}_{\mathrm{b}} \\
& \text { Beta }- \text { Carotene }=-0.430 A_{412}+0.251 A_{431}-13.216 A_{480}
\end{aligned}
$$

Total lipids were analyzed after centrifugation at $2000 \mathrm{rpm}$ for 15 minutes (IEC HN-S centrifuge). The supernatant was removed carefully, the pellet was weighed as fresh weight and kept at $-20{ }^{\circ} \mathrm{C}$. The total lipid was extracted from the fresh cells according to Bligh and Dyer (1959) with a mixture of chloroform:methanol: $\mathrm{NaCl} 1 \%$ 
$(2: 1: 2 \mathrm{v} / \mathrm{v})$. The pellet was heated in a microwave to break down the cell membranes. Methanol was added, the pellet vortexed for 5 minutes, then chloroform and $\mathrm{NaCl} 1 \%$ were added. The mixture was centrifuged at $2000 \mathrm{rpm}$ for 10 minutes to obtain a clear supernatant. The supernatant was removed and the bottom solution was dried using $\mathrm{N}_{2}$ bubbling, which included lipid and chloroform. After complete drying, the remaining material was weighed to obtain the amount of total lipid per fresh weight biomass.

The method of Mahalingam et al. (2006) was applied to measure the total ROS (reactive oxygen species) levels. The algal suspension was harvested, cells were centrifuged (IEC HN-S centrifuge) at $2000 \mathrm{rpm}$ for 15 minutes, and then the supernatant was removed. The precipitate was mixed with $10 \mathrm{mM}$ Tris- $\mathrm{HCl}$ buffer $(\mathrm{pH}$ 7.2). The suspensions were homogenized by the ultrasonic method for 10 minutes. Finally, the obtained homogenates were centrifuged at 14000 rcf for 20 minutes at $4^{\circ} \mathrm{C}$. The supernatant $(900 \mu \mathrm{L})$ was mixed with 1mM 2', 7'-dichlorofluorescin diacetate (DCFDA) solution in dimethyl sulfoxide (DMSO) and vortexed for 30 seconds. The samples were placed in dark for 15 minutes and fluorescence was measured with a spectrofluorometer (F90 fluorescence spectrophotometer) at $480 \mathrm{~nm}$. The total protein concentration of samples was measured using the Biuret method (Gornall et al., 1949). Data were expressed as relative fluorescence units (RFU) per $\mathrm{g} \mathrm{mL}^{-1}$ of protein.

\section{STATISTICAL ANALYSIS}

All experiments were performed at least in three replicates. The data were expressed as mean $\pm \mathrm{SD}$ (standard deviation). The normality tests (Descriptive Statistics/ Frequencies) were performed before ANOVA. Differences between treatments were determined at $p<0.05$ using factorial analysis of variance (one-way ANOVA) with a Tukey multiple comparisons post hoc test. Cell growth, chlorophyll and beta-carotene concentration were compared between treatments using repeated-measures ANOVA. Data of total chlorophyll concentration under treatment of glucose, were not normal, therefore, differences between treatments were determined at $p<0.05$ using Kruskal-Wallis. All statistics were carried out using the SPSS software (version 23 for Windows; SPSS Inc., Chicago, IL, USA).

\section{RESULTS}

\section{THE EFFECTS OF GLUCOSE AND ACETATE AS TWO DIFFERENT SOURCES OF ORGANIC CARBON}

In this study, optimization of two organic carbon sources namely glucose and acetate was studied under the autotrophic (control, no glucose), mixotrophic, and heterotrophic conditions. In the presence of glucose (Figure 1A), cell concentration in all treatments was similar until day 4 of experiment. After 1 week, a high increase was observed at glucose concentrations of 40,60 and $80 \mathrm{mM}$, which corresponded to 45,33 and $33 \times 106$ cells per $\mathrm{mL}$, respectively. By increasing glucose concentration above $60 \mathrm{mM}$, a significant decrease $(26 \%)$ in cell number was observed. Until day 4, no difference was found in chlorophyll and beta-carotene concentrations between the control and the various glucose treatments (Figures $1 \mathrm{~B}$ and $2 \mathrm{~A}$ ). After two weeks, chlorophyll decreased from 20 (control) to $5 \mu \mathrm{g} \mathrm{mL}^{-1}$ (Figure 1B), and beta-carotene went from 8 (control) to $3 \mu \mathrm{g}$ $\mathrm{mL}^{-1}$ (Figure 2A). An increase was found in lipid production after one week under glucose treatments of 20,40 and $60 \mathrm{mM}$, but lipid production returned to initial levels after two weeks, in all glucose concentrations (Figure 2B). After two weeks, a decrease was observed in lipid production (from 0.22 to 0.1 ) with all glucose concentrations.

By using acetate in the mixotrophic culture, a slight increase in cell concentration was observed (Figure $3 \mathrm{~A})$ compared to the autotrophic condition (control, no acetate). In all concentrations of acetate (50, 100 and $150 \mathrm{mM}$ ), total chlorophyll (Figure $3 \mathrm{~B}$ ) and beta-carotene

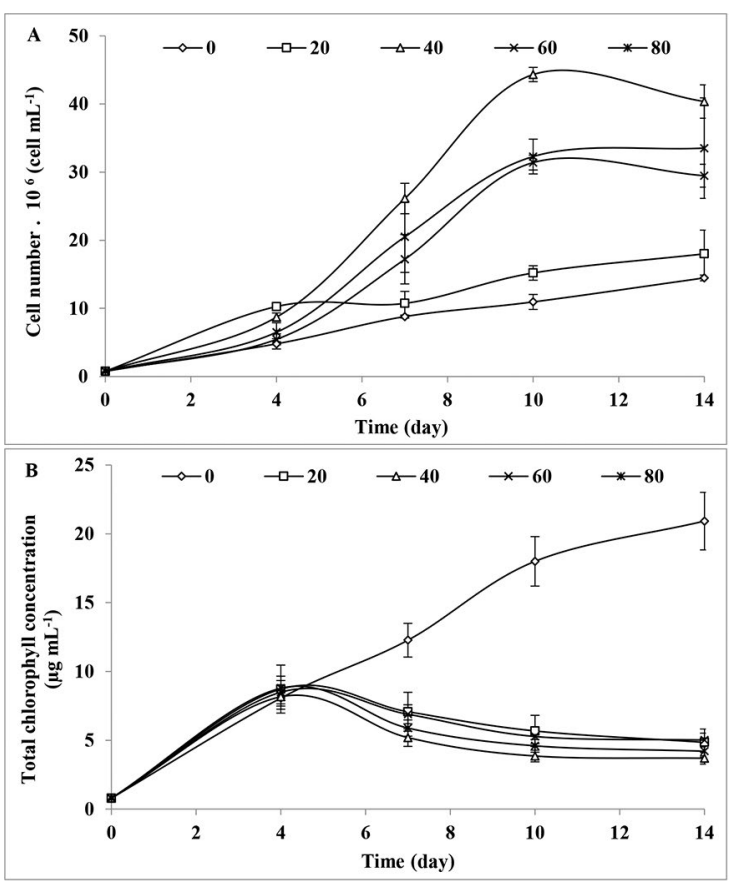

Figure 1. Effects of different concentrations of glucose (mM) on A. Cell number (cell $\left.\mathrm{mL}^{-1}\right)$, and $\mathrm{B}$. Total chlorophyll concentration $\left(\mu \mathrm{g} \mathrm{mL}^{-1}\right)$ of Dunaliella bardawil $(=D$. salina $)$ in mixotrophic culture in comparison with autotrophic condition (control = zero concentration). The data are expressed as mean \pm standard deviation of three replicates. 


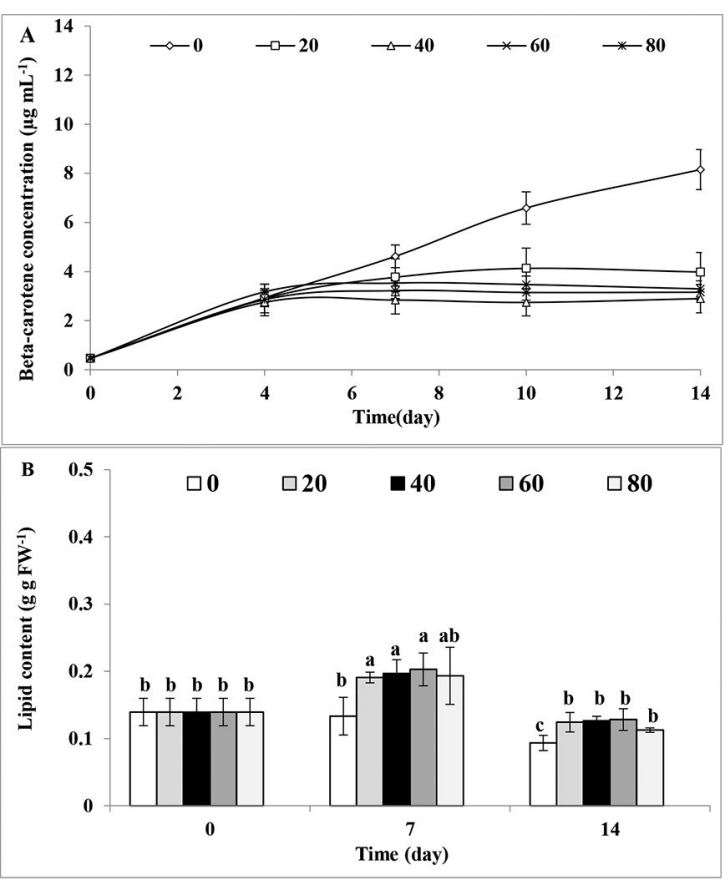

Figure 2. Effects of different concentrations of glucose (mM) on A. Beta-carotene concentration $\left(\mu \mathrm{g} \mathrm{mL}^{-1}\right)$, and B. Lipid production ( $\mathrm{g} \mathrm{g}$ $\left.\mathrm{FW}^{-1}\right)$ of Dunaliella bardawil $(=D$. salina $)$ in mixotrophic culture in comparison with autotrophic condition (control = zero concentration). The data are expressed as mean \pm standard deviation of three replicates. Different letters in $\mathrm{b}$ indicate significant difference at $p<$ 0.05 according to Tukey test.
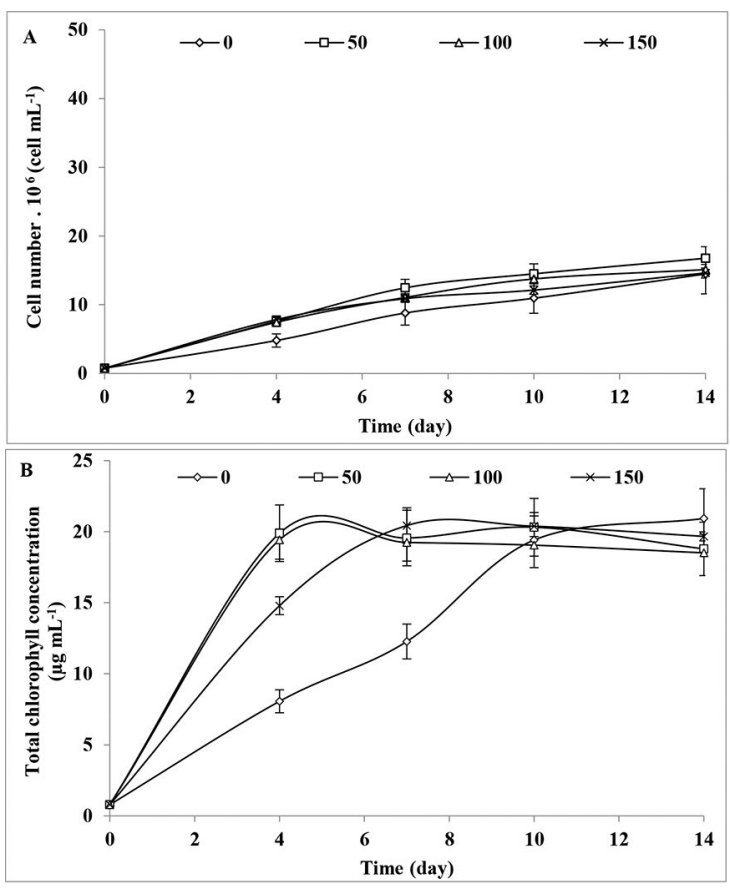

Figure 3. Effects of different concentrations of acetate $(\mathrm{mM})$ on A. Cell number (cell $\left.\mathrm{mL}^{-1}\right)$, and $\mathrm{B}$. Total chlorophyll concentration $\left(\mu \mathrm{g} \mathrm{mL}^{-1}\right)$ of Dunaliella bardawil $(=D$. salina $)$ in mixotrophic culture in comparison with autotrophic condition (control = zero concentration). The data are expressed as mean \pm standard deviation of three replicates.

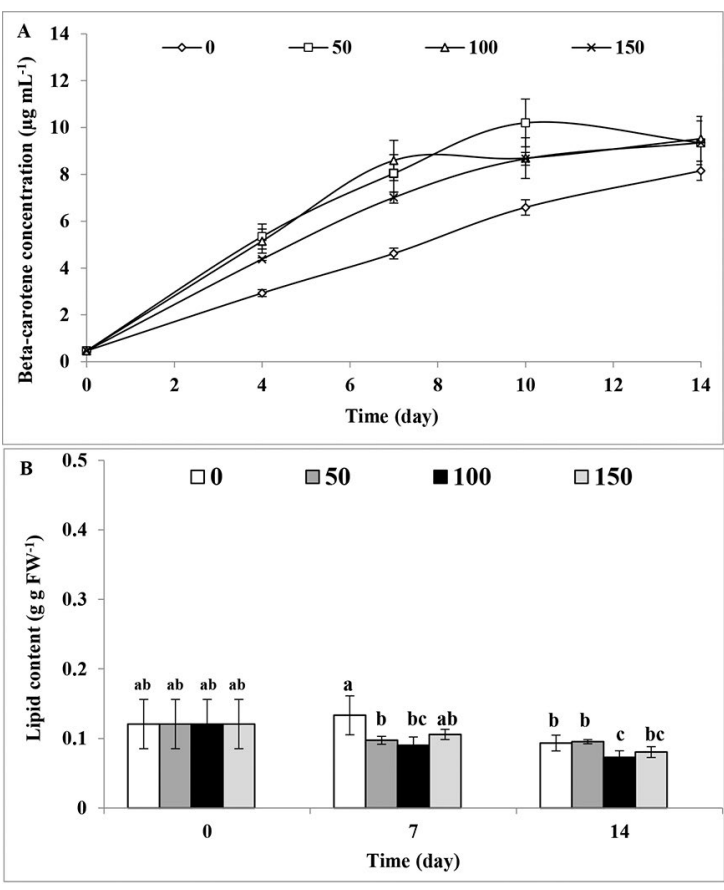

Figure 4. Effects of different concentrations of acetate $(\mathrm{mM})$ on $\mathrm{A}$. Beta-carotene concentration $\left(\mu \mathrm{g} \mathrm{mL}^{-1}\right)$, and B. Lipid production ( $\mathrm{g} g$ $\left.\mathrm{FW}^{-1}\right)$ of Dunaliella bardawil $(=D$. salina $)$ in mixotrophic culture in comparison with autotrophic condition (control = zero concentration). The data are expressed as mean \pm standard deviation of three replicates. Different letters in B indicate significant difference at $p<$ 0.05 according to Tukey test.

concentrations (Figure 4A) showed a significant increase $(p<0.05)$. During 4 days, the highest increase in total chlorophyll was obtained at $20 \mu \mathrm{g} \mathrm{mL}^{-1}$ at concentrations of 50 and $100 \mathrm{mM}$, indicating a three- time increase compared to the control. After 1 week, the concentration of chlorophyll at $150 \mathrm{mM}$ of acetate reached about $20 \mu \mathrm{g}$ $\mathrm{mL}^{-1}$ (Figure 3B), similar to other concentrations of acetate in the medium. Finally, after 2 weeks, the total chlorophyll concentration was similar at all concentrations of acetate and control (autotrophic condition), and it was about $20 \mu \mathrm{g}$ $\mathrm{mL}^{-1}$. As shown in Figure 4A, beta-carotene concentration at all concentration of acetate increased about $7.8 \mu \mathrm{g} \mathrm{mL}^{-1}$ (day 7), and $9.2 \mu \mathrm{g} \mathrm{mL}^{-1}$ (day 10) compared to the control (corresponding values of 4.6 and 6.5, respectively). By increasing the concentrations above than $100 \mathrm{mM}$, the trend of increase in total concentrations of chlorophyll decreased from 20 to $13 \mu \mathrm{g} \mathrm{mL} \mathrm{m}^{-1}$ (within 4 days), and for beta-carotene, it decreased (within 7 days) from 8 to $7 \mu \mathrm{g} \mathrm{mL} \mathrm{mL}^{-1}$. As shown in Figure 4B, using acetate in the culture medium resulted in a decrease in lipid production about $21 \%$ in all different concentrations of acetate over two weeks $(p<0.05)$. After 4 days, the highest increase in total chlorophyll $\left(20 \mu \mathrm{g} \mathrm{mL}^{-1}\right)$ was obtained at acetate 
concentrations of 50 and $100 \mathrm{mM}$, indicating a three-time increase compared to the control (Figure 3B). The same chlorophyll concentration was attained only after 1 week at $150 \mathrm{mM}$ of acetate (Figure 3B). After 2 weeks, the total chlorophyll concentration was similar at all concentrations of acetate and control (autotrophic condition), leveling at $20 \mu \mathrm{g} \mathrm{mL}^{-1}$. Beta-carotene concentration at all concentrations of acetate increased compared to the control (Figure 4A). By increasing the acetate concentration above $100 \mathrm{mM}$, beta-carotene decreased from 8 to $7 \mu \mathrm{g}$ $\mathrm{mL}^{-1}$ within 7 days. Using acetate in the culture medium resulted in a $21 \%$ decrease in lipid production over two weeks, regardless of acetate concentration.

Under heterotrophic condition (no light) and various concentrations of glucose and acetate, cell concentration, chlorophyll content and beta-carotene concentration were always lower than the control, represented by the autotrophic condition. Heterotrophic and autotrophic concentration maxima for the above-mentioned parameters were, respectively, $2.5 \times 10^{6}$ cell $\mathrm{mL}^{-1}$ and 13 $\times 10^{6}$ cell $\mathrm{mL}^{-1}$ (cell concentration), $1 \mu \mathrm{g} \mathrm{mL} \mathrm{m}^{-1}$ and $20 \mu \mathrm{g}$ $\mathrm{mL}^{-1}$ (chlorophyll), and $0.5 \mu \mathrm{g} \mathrm{mL}^{-1}$ and $7 \mu \mathrm{g} \mathrm{mL}^{-1}$ (betacarotene). In various acetate and glucose concentrations, all the measured parameters were close to zero (data not shown). Therefore, lipid content was not estimated for the heterotrophic condition.

As shown in Figure 5A, after 4 days, the production of ROS had a slight increase of about $28 \%$ at a glucose concentration of $80 \mathrm{mM}$. After 1 week, the ROS level decreased to $100 \mathrm{RFU} / \mathrm{g} \mathrm{mL}^{-1}$ protein at all concentrations of glucose and acetate. No significant changes were observed in the total ROS levels 4 days after addition of $150 \mathrm{mM}$ acetate (Figure 5B).

\section{DISCUSSION}

Microalgae may store a large part of their dry weight as lipids (Chisti, 2008), and culture optimization is needed to enhance lipid production for industrial and nutritional applications. Considering cellular self-shading and photoinhibition in autotrophic cultures (Kim et al., 2013) and the consequent reduction of biomass production, heterotrophic and mixotrophic cultures could be envisaged as alternatives to increase lipid content (Liang et al., 2009; Bumbak et al., 2011). However, the present results showed that cell concentration of D. bardawil (= D. salina) is very low in heterotrophic conditions with various concentrations of glucose and acetate. This is

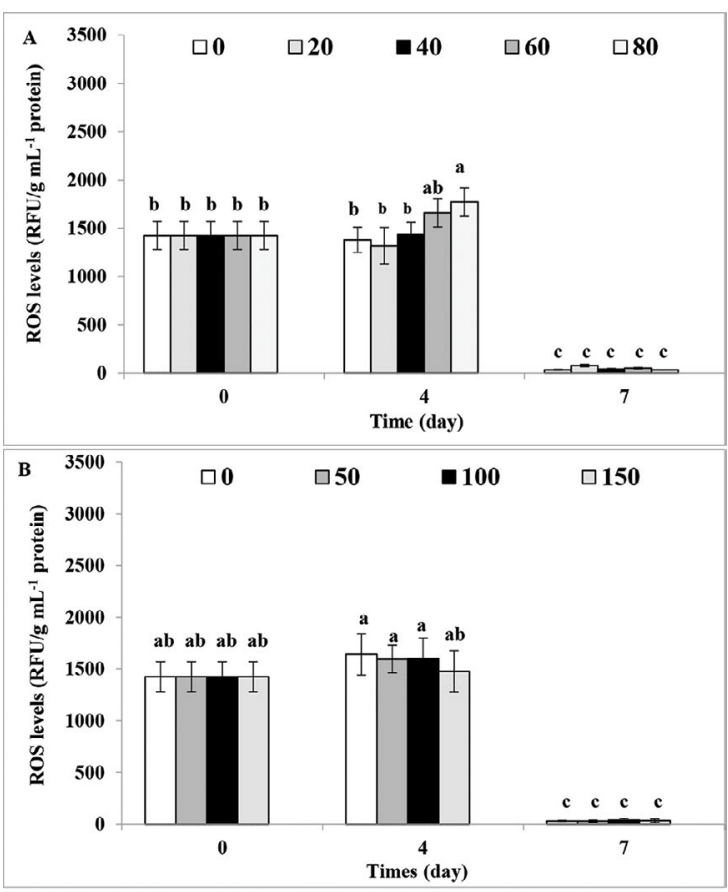

Figure 5. The intracellular ROS levels (RFU/g mL ${ }^{-1}$ protein) in the presence different concentrations of A. Glucose $(\mathrm{mM})$, and B. Acetate $(\mathrm{mM})$ in Dunaliella bardawil $(=$ D. salina $)$ in comparison with autotrophic condition (control $=$ zero concentration). The data are expressed as mean \pm standard deviation of three replicates. Different letters indicate significant difference at $p<0.05$ according to Tukey test.

not surprising, since Dunaliella is an obligated autotroph (Subba Rao, 2009), and the growth rate of Dunaliella species has been previously reported as very low in heterotrophic conditions (Hard and Gilmoure, 1996).

High growth rates were observed at different concentrations of glucose (mixotrophic condition), compared to the control (autotrophic condition). In mixotrophic conditions, due to the presence of glucose as an organic carbon source, cell growth increased and length of growth period decreased, as cell division was not entirely dependent on photosynthesis (Cheirsilp and Torpee, 2012). The presence of light and organic carbon, as simultaneous sources of energy in mixotrophic conditions, allows both autotrophic and heterotrophic processes to take place (Facundo et al., 1993), leading to an increase in the growth rate. Organic carbon sources are expected to reduce $\mathrm{CO}_{2}$ fixation through photosynthesis. In such scenario, while cell division increases, the metabolic cost of respiration may exceed the gain from photosynthesis (Liu et al., 2009; Rym et al., 2010). Photosynthetic microorganisms can use glucose in their metabolism as the final production of photosynthesis. Glucose has more energy per mole than other substrates (Boyle and Morgan, 2009) and seems to stimulate cell 
growth (Garcia et al., 2005). Higher growth and respiration rates were reported with the use of glucose compared to other substrates, such as sugars and organic acids (Griffiths et al., 1960). High concentrations of glucose $(>60 \mathrm{mM})$ reduce cell division, which may be explained by substrate inhibition of some enzymes (Garcia et al., 2005; Reed et al., 2010).

The lower concentrations of chlorophyll and betacarotene in the presence of glucose in mixotrophic conditions are likely to be related to an increase in the heterotrophic metabolism of glucose (Shihira-Ishikawa and Hase, 1964), and to the destruction of chlorophyll $a$ in response to a decrease in the number of thylakoid membranes in chloroplast (Stadnichuk et al., 1998; Anila et al., 2013). The increase in ROS levels in the presence of glucose seems to cause the chlorophyll degradation (Cuello and Lahora, 1993). Increase in the synthesis of chlorophyll and beta-carotene in D. bardawil (=D. salina) can be due to the presence of acetate, as precursor of acetyl CoA (Murphy and Walker 1982). Acetyl CoA is a precursor of beta-carotene synthesis pathway (Sasso et al., 2012) in several organisms (Lichtenthaler, 1999), including Dunaliella (Ben-Amotz and Shaish, 1992). It also acts in the biosynthesis of phytol, a lateral chain of chlorophylls (Paniagua-Michel et al., 2012). Seemingly, acetate contributes in the beta-carotene and chlorophyll synthesis by producing acetyl CoA.

In the presence of glucose in mixotrophic conditions after 1 week, the lipid levels were about 1.5 times higher than in the autotrophic condition. Considering that acetylCoA is also a precursor in lipid biosynthesis pathways (Ren et al., 2009), it seems that glucose as an organic carbon source influences lipid production by providing additional energy and products, such as Acetyl-CoA and NADPH, which are essential for lipid accumulation in microorganisms (Ren et al., 2009). However, increase of lipid levels in the presence of glucose was associated with a decrease in beta-carotene concentration, lipid content decreased along with an enhancement in beta-carotene concentration in the presence of acetate. As lipids and beta-carotene have the same precursor (Paniagua-Michel et al., 2009), different conditions may influence carbon partitioning toward beta-carotene or lipid production (Juneja et al., 2013). Apparently, decrease in the betacarotene concentration under the glucose treatment and increase in the beta-carotene concentration in the acetate treatment led to an increase and decrease in lipid content, respectively (Bonnefond et al., 2017).
Increase in the ROS production in response to high glucose concentration, and lack of changes in the presence of acetate, can also be attributed to the low and high betacarotene concentration, respectively. It seems that in the presence of glucose, low concentrations of beta-carotene are not able to prevent ROS production (Jiménez and Pick, 1993).

\section{CONCLUSION}

The results of the present study on $D$. bardawil ( $=D$. salina) cultivation showed that the mixotrophic culture containing glucose is the most suitable alternative for high cell growth and lipid production. The mixotrophic culture containing acetate was also found as a better alternative to high production of beta-carotene in a short time interval (about one week). As an obligate autotroph, Dunaliella has a very low cell division in the heterotrophic treatment, therefore lipid production is not recommended in such condition.

\section{ACKNOWLEDGEMENTS}

We would like to thank the Graduate School of the University of Isfahan for providing research facilities for this study. Authors acknowledge Plant Antioxidant Center of Excellence (PACE), University of Isfahan.

\section{REFERENCES}

ANILA, N., SIMON, D. P., CHANDRASHEKAR, A. P. \& SARADA, R. 2013. Glucose-induced activation of $\mathrm{H}^{+}-$ ATPase in Dunaliella salina and its role in hygromycin resistance. Journal of Applied Phycology, 25, 121-128.

BEN-AMOTZ, A. 2004. Industrial production of microalgal cell-mass secondary products -Major industrial species: Dunaliella. In: Handbook of microalgal culture: Biotechnology and applied phycology. Iowa: Blackwell Press.

BEN-AMOTZ, A. \& SHAISH, A. 1992. $\beta$-carotene biosynthesis. In: Dunaliella: Physiology, Biochemistry, and Biotechnology. Boca Raton: CRC Press.

BEN-AMOTZ, A., SUSSMAN, I. \& AVRON, M. 1982. Glycerol production by Dunaliella. Experientia, 38, 49-52.

BLIGH, E. G. \& DYER, W. J. 1959. A rapid method for total lipid extraction and purification. Canadian Journal of Biochemistry and Physiology, 37, 911-917.

BONNEFOND, H., MOELANTS, N., TALEC, A., MAYZAUD, P., BERNARD, O. \& SCIANDRA, A. 2017. Coupling and uncoupling of triglyceride and beta-carotene production by Dunaliella salina under nitrogen limitation and starvation. Biotechnology for Biofuels, 10, 25.

BOROWITZKA, M. A. 1999. Commercial production of microalgae: Ponds, tanks, tubes and fermenters. Journal of Biotechnology, 70, 313-321. 
BOROWITZKA, M. A. 2016. Systematics, Taxonomy and Species Names: Do They Matter? In: BOROWITZKA, M. A., BEARDALL, J. \& RAVEN, J. A. (eds.) The physiology of Microalgae. Switzerland: Springer International Publishing.

BOYLE, N. R. \& MORGAN, J. A. 2009. Flux balance analysis of primary metabolism in Chlamydomonas reinhardtii. BMC Systems Biology, 3, 4.

BUMBAK, F., COOK, S., ZACHLEDER, V., HAUSER, S. \& KOVA, K. 2011. Best practices in heterotrophic highcell-density microalgal processes: achievements, potential and possible limitations. Applied Microbiology and Biotechnology, 91, 31-46.

CAPA-ROBLES, W., PANIAGUA-MICHEL, J. \& SOTO, J. O. 2009. The biosynthesis and accumulation of $\beta$-carotene in Dunaliella salina proceed via the glyceraldehyde 3-phosphate/pyruvate pathway. Natural Product Research, 23, 1021-1028.

CHEIRSILP, B. \& TORPEE, S. 2012. Enhanced growth and lipid production of microalgae under mixotrophic culture condition: effect of light intensity, glucose concentration and fed-batch cultivation. Bioresource Technology, 110, 510-516.

CHISTI, Y. 2007. Biodiesel from microalgae. Biotechnology Advances, 25, 294-306.

CHISTI, Y. 2008. Biodiesel from microalgae beats bioethanol. Trends in Biotechnology, 26, 126-131.

CHOJNACKA, K. \& MARQUEZ-ROCHA, F. J. 2004. Kinetic and stoichiometric relationships of the energy and carbon metabolism in the culture of microalgae. Biotechnology, 3, 21-34.

CUELLO, J. \& LAHORA, A. 1993. Chlorophyll degradation by free radicals derived from linolenic acid in incubated barley thylakoids. Acta Botanica Neerlandica, 42, 481-490.

DE SWAAF, M. E., SIJTSMA, L. \& PRONK, J. T. 2003. Highcell-density fed-batch cultivation of the docosahexaenoic acid producing marine alga Crypthecodinium cohnii. Biotechnology and Bioengineering, 81, 666-672.

EIJCKELHOFF, C. \& DEKKER, J. P. 1997. A routine method to determine the chlorophyll $a$, pheophytin $a$ and $\beta$-carotene contents of isolated Photosystem II reaction center complexes. Photosynthesis Research, 52, 69-73.

FACUNDO, J. M., SASAKI, K., KAKIZONO, T., NISHIO, N. \& NAGAI, S. 1993. Growth characteristics of Spirulina platensis in mixotrophic and heterotrophic conditions. Journal of Fermentation and Bioengineering, 76, 408-410.

GARCIA, M. C. C., MIRÓN, A. S., SEVILLA, J. M. F., GRIMA, E. M. \& CAMACHO, F. G. 2005. Mixotrophic growth of the microalga Phaeodactylum tricornutum: influence of different nitrogen and organic carbon sources on productivity and biomass composition. Process Biochemistry, 40, 297-305.

GORNALL, A. G., BARDAWILL, C. J. \& DAVID, M. M. 1949. Determination of Serum Proteins by Means of the Biuret Reaction. Journal of Biological Chemistry, 177, 751-766.

GOUVEIA, L. \& OLIVEIRA, A. C. 2009. Microalgae as a raw material for biofuels production. Journal of Industrial Microbiology and Biotechnology, 36, 269-274.

GRIFFITHS, D. J., THRESHER, C. L. \& STREET, H. E. 1960. The heterotrophic nutrition of Chlorella vulgaris. Annals of Botany, 24, 1-11.

HARD, B. C. \& GILMOUR, D. J. 1996. The uptake of organic compounds by Dunaliella parva CCAP 19/9. European Journal of Phycology, 31, 217-224.
HOSEENI TAFRESHI, A. \& SHARIATI, M. 2006. Pilot culture of three strains of Dunaliella salina for $\beta$-carotene production in open ponds in the central region of Iran. World Journal of Microbiology and Biotechnology, 22, 1003-1006.

JIMÉNEZ, C. \& PICK, U. 1993. Differential Reactivity of $\beta$-Carotene Isomers from Dunaliella bardawil toward oxygen radicals. Plant Physiology, 101, 385-390.

JOHNSON, M. K., JOHNSON, E. J., MacELROY, R. D., SPEER, H. L. \& BRUFF, B. S. 1968. Effect of salt on the halophilic alga Dunaliella viridis. Journal of Bacteriology, 95, 1461-1468.

JUNEJA, A., CEBAllos, R. M. \& MURTHY, G. S. 2013. Effects of Environmental Factors and Nutrient Availability on the Biochemical Composition of Algae for Biofuels Production. Energies, 6, 4607-4638.

KIM, S., PARK, J. E., CHO, Y. B. \& HWANG, S. J. 2013. Growth rate, organic carbon and nutrient removal rates of Chlorella sorokiniana in autotrophic, heterotrophic and mixotrophic conditions. Bioresource Technology, 144, 8-13.

LEE, Y. K. 2004. Algal nutrition: heterotrophic carbon nutrition. In: Handbook of microalgal culture: Biotechnology and Applied Phycology. Oxford: Blackwell Press.

LIANG, Y., SARKANY, N. \& CUI, Y. 2009. Biomass and lipid productivities of Chlorella vulgaris under autotrophic, heterotrophic and mixotrophic growth conditions. Biotechnology Letters, 31, 1043-1049.

LICHTENTHALER, H. K. 1999. The 1-deoxy-D-xylulose-5phosphate pathway of isoprenoid biosynthesis in plants. Annual Review of Plant Physiology and Plant Molecular Biology, 50, 47-65.

LIU, X., DUAN, S., LI, A., XU, N., CAI, Z. \& HU, Z. 2009. Effects of organic carbon sources on growth, photosynthesis, and respiration of Phaeodactylum tricornutum. Journal of Applied Phycology, 21, 239-246.

MAHALINGAM, R., JAMBUNATHAN, N., GUNJAN, S. K., FAUSTIN, E., WENG, H. \& AYOUBI, P. 2006. Analysis of oxidative signalling induced by ozone in Arabidopsis thaliana. Plant, Cell and Environment, 29, 1357-1371.

MARTINEZ, F. \& ORUS, M. I. 1991. Interactions between glucose and inorganic carbon metabolism in Chlorella vulgaris strain UAM 1011. Plant Physiology, 95, 1150-1155.

MIAO, X. \& WU, Q. 2006. Biodiesel production from heterotrophic microalgal oil. Bioresource Technology, 97, 841-846.

MURPHY, D. J. \& WALKER, D. A. 1982. Acetyl coenzyme A biosynthesis in the chloroplast: What is the physiological precursor? Planta, 156, 84-88.

PANIAGUA-MICHEL, J., CAPA-ROBLES, W., OLMOSSOTO, J. \& GUTIERREZ-MILLAN, L. E. 2009. The carotenogenesis pathway via the isoprenoid- $\beta$-carotene interference approach in a new strain of Dunaliella salina isolated from Baja California Mexico. Marine Drugs, 7, 4556.

PANIAGUA-MICHEL, J., OLMOS-SOTO, J. \& RUIZ, M. A. 2012. Pathways of carotenoid biosynthesis in bacteria and microalgae. Methods in Molecular Biology, 892, 1-12.

REED, M. C., LIEB, A. \& NIJHOUT, H. F. 2010. The biological significance of substrate inhibition: a mechanism with diverse functions. Bioessays, 32, 422-429.

REN, L. J., HUANG, H., XIAO, A. H., LIAN, M., JIN, L. J. \& JI, X. J. 2009. Enhanced docosahexaenoic acid production by reinforcing acetyl-CoA and NADPH supply in Schizochytrium sp. HX-308. Bioprocess and Biosystems Engineering, 32, 837-843. 
RYM, B. D., NEJEH, G., LAMIA, T., ALI, Y., RAFIKA, C., KHEMISSA, G., JIHENE, A., HELA, O. \& HATEM, B. O. 2010. Modeling growth and photosynthetic response in Arthrospira platensis as function light intensity and glucose concentration using factorial design. Journal of Applied Phycology, 22, 745-752.

RATLEDGE, C. \& EVANS, C. T. 1989. Lipids and their metabolism. In: ROSE, A. H. \& HARRISON, J. S. (eds.) The yeasts. London: Academic Press.

SASSO, S., POHNERT, G., LOHR, M., MITTAG, M. \& HERTWECK, C. 2012. Microalgae in the postgenomic era: a blooming reservoir for new natural products. FEMS Microbiology Reviews, 36, 761-785.

SCHENK, P. M., THOMAS-HALL, S. R., STEPHENS, E., MARX, U. C., MUSSGNUG, J. H. \& POSTEN, C., et al. 2009. Second generation biofuels: high-efficiency microalgae for biodiesel production. BioEnergy Research, 1, 20-43.

SCHOEN, S. 1988. Cell counting. In: LOBBAN, C. S., CHAPMANS D. J. \& KREMER B. P. (eds.) Experimental Phycology: a laboratory manual. Cambridge: Cambridge University Press.

SHARIATI, M. \& LILLEY, R. McC. 1994. Loss of intracellular glycerol from Dunaliella by electroporation at constant osmotic pressure: subsequent restoration of glycerol content and associated volume changes. Plant, Cell and Environment, 17, 1295-1304.

SHARMA, K. K., SCHUHMANN, H. \& SCHENK, P. M. 2012. High Lipid Induction in Microalgae for Biodiesel Production. Energies, 5, 1532-1553.

SHIHIRA-ISHIKAWA, I. \& HASE, E. 1964. Nutritional control of cell pigmentation in Chlorella protothecoides with special reference to the degeneration of chloroplast induced by glucose. Plant and Cell Physiology, 5, 227-240.
STADNICHUK, I. N., RAKHIMBERDIEVA, M. G., BOLYCHEVTSEVA, Y. V., YURINA, N. P., KARAPETYAN, N. V. \& SELYAKH, I. O. 1998. Inhibition by glucose of chlorophyll $a$ and phycocyanobilin biosynthesis in the unicellular red alga Galdieria partita at the stage of coproporphyrinogen III formation. Plant Science, 136, 11-23.

SUBBA RAO, D. V. 2009. Cultivation, Growth Media, Division Rates and Applications of Dunaliella Species. In: BENAMOTZ, A., JURGEN, E. W. P. \& SUBBA RAO, D. V. (eds.) The Alga Dunaliella: Biodiversity, Physiology, Genomics and Biotechnology. Enfiled: Science Publishers.

SUN, N., WANG, Y., LI, Y. T., HUANG, J. C. \& CHEN, F. 2008. Sugar-based growth, astaxanthin accumulation and carotenogenic transcription of heterotrophic Chlorella zofingiensis (Chlorophyta). Process Biochemistry, 43, 12881292.

TAKAGI, M., KARSENO, Y. \& YOSHIDA, T. 2006. Effect of salt concentration on intracellular accumulation of lipids and triacylglyceride in marine microalgae Dunaliella cells. Journal of Bioscience and Bioengineering, 101, 223-226.

VANITHA, A., NARAYAN, M. S., MURTHY, K. N. C. \& RAVISHANKAR, G. A. 2007. Comparative study of lipid composition of two halotolerant algae, Dunaliella bardawil and Dunaliella salina. International Journal of Food Science and Nutrition, 58, 373-382.

YU, H., JIA, S. \& DAI, Y. 2009. Growth characteristics of the cyanobacterium Nostoc flagelliforme in photoautotrophic, mixotrophic and heterotrophic cultivation. Journal of Applied Phycology, 21, 127-133. 